\title{
The influence of brand awareness, brand association and product quality on brand loyalty and repurchase intention: a case of male consumers for cosmetic brands in South Africa
}

\author{
Richard Chinomona \\ Eugine Tafadzwa Maziriri \\ Marketing Division \\ School of Economic and Business Sciences \\ Faculty of Commerce, Law \& Management \\ University of the Witwatersrand
}

\section{Keywords}

Brand awareness, brand association, product quality; repurchase intention, cosmetics, brands, male consumers.

\begin{abstract}
This study assessed the influence of brand awareness, brand association and product quality on brand loyalty and repurchase intention among male consumers of cosmetic brands in South Africa. It is also imperative to note that, despite the theoretical contributions made by many scholars on repurchase intention of various brands, they seem to be a paucity of studies that have investigated the influence of brand awareness, brand association and product quality on brand loyalty and repurchase intention. The study utilized a quantitative research design using a structured questionnaire. In addition, they study made use of a sample of male consumers in Gauteng province of South Africa. Four hypotheses were posited and to empirically test these hypotheses, a sample data set of 150 was used. The findings indicate that brand awarenesshas a positive and significant influence on brand loyalty, brand association has a positive and insignificant influence on brand loyalty, product quality has a positive and significant influence on brand loyalty and brand loyalty exerts a positive and significant influence on purchase intention. The empirical study provided fruitful implications to academicians by making a significant contribution to the brand management literature by systematically exploring the influence of brand awareness, brand association and product quality on brand loyalty and repurchase intention. This study therefore, stand to immensely contribute new knowledge to the existing body of brand management literature in Africa - a context that is often most neglected by some researchers in developing countries.
\end{abstract}

Corresponding author: Eugine Tafadzwa Maziriri

Email address for corresponding author: eugine.maziriri@wits.ac.za

First submission received: 16th March 2017

Revised submission received: 25th May 2017

Accepted: 9th June 2017

\section{Introduction}

In today's post-modern era, repurchase intention is a valuable force to improve a company's profit and sustainable growth. Repurchase intention involves the individual's judgment about buying again a designated service from the same company, considering his or her current situation and likely circumstances. Some studies have concentrated on determining the basic antecedent variables to repurchase intention (Hocutt, 1998; Storbackaet al., 1994; Zahorik\& Rust, 1992). In addition, a host of marketing studies such as, for example, Anderson et al. (1994) and Hennig-Thurau\& Klee (1997), have acknowledged that the good experiences of customers lead to re-consumption in the future. In addition, continuous repurchase behavior by consumers results in higher profit margins, competitive advantage and faster business growth (Chinomona \& Dubihlela 2014, Singh \& Khan, 2012; Farquahar, 2003). 
An interrogation on the repurchase intention is not new. Significant research on the subject has been done in various contexts by focusing on what attracts Chinese customers to repurchase Korean cosmetcis (Sun, Kim \&Heo 2016); does customer satisfaction lead to customer trust, loyalty and repurchase intention of local store brands (Chinomona \& Dubihlela 2014), investigating factors that lead to repurchase (Hellier, Geursen, Carr\&Rickard, 2002), the impact of brand trust, self-image congruence and usage satisfaction toward smartphone repurchase intention (Goh, Jiang \& Tee 2016), Factors affecting positive word of mouth and repurchase intention (Itsarintr, 2011), the impact of brand trust and satisfaction on retailer repurchase intentions (Zboja, \& Voorhees 2006) and the influence of female university students' cosmetic purchase motivation on cosmetic attribute evaluation and brand repurchase intention (Park \& Ku 2009).

All these studies point a general consensus that customer repurchase intention can yield several economic advantages (Buttle, 2004). Since customers are key predecessors for sales, business' growth and profitability (Owusuah, 2012; Rust \& Chung, 2006; Thompson, 2005). Previous studies have left a gap on the influence of brand awareness, brand association and product quality on brand loyalty as a mediator variable with the end result of causing repurchase intention among male consumes of cosmetic brands. Premised on the identified research gap, the current study seeks to investigate the influence of brand awareness, brand association and product quality on brand loyalty and repurchase intention among male consumers of cosmetic brands in South Africa. Above and beyond, the current study is expected to make academic and practical contributions to the existing branding literature and the practice of branding management in developing countries - South Africa in particular.

\section{Literature review}

Pamacheche, Chinomona and Chuchu (2016) posits that literature serves the purposes of sharing findings of other studies related to the study at hand, relating the study to a larger ongoing conversation in literature as well as fillings gaps and extending prior studies. The literature review will comprise: theoretical framework and empirical review.

\subsection{The theoretical framework}

A theoretical framework is a well-developed explanation of events that helps the researchers to locate their studies and to signal the origin of their proposed research (Vithal\&Jansen 2010). This study is anchored in the framework of the theory of planned behavior (abbreviated TPB), since repurchase intention can be subsumed under the more general concept of "behavioral intention" which includes intentions other than those related to repurchases, e.g. intention to purchase a product further, word-of-mouth intentions, and complaint intentions (Ahmed 2014). According to the theory of planned behavior, intention is viewed as an immediate antecedent of actual behavior (Lin \& Chen 2010).

\subsection{Theory of planned behavior}

The theory of planned behavior aids this research by providing a theoretical mechanism through which the link between brand loyalty and repurchase intention can be established. The theory of planned behavior is one of the most influential and well-supported social psychological theories for predicting human behavior (Ajzen, 1985). Tsai (2010) points out that the TPB supposes that individual behavior is influenced by behavioral beliefs, normative beliefs and control beliefs. In addition, Tsai (2010) behavioral beliefs can generate the attitude of an individual towards a behavior normative beliefs lead to the subjective norms of an individual and control beliefs are the perceived behavioral control of an individual. Furthermore, the theory of planned behavior (TPB) predicts that planned behaviors are determined by behavioral intentions which are largely influenced by an individual's attitude toward a behavior, the subjective norms encasing the execution of the behaviors, and the individual's perception of their control over the behavior (Ajzen, 1991). Moreover, explained that the TPB can provide useful insight into the processes that translate 
positive attitudes or evaluations into purchase intentions and purchase behavior (Smith, Terry, Manstead, Louis, Kotterman\& Wolfs 2007).

\section{Empirical review}

\subsection{Brand awareness}

Brand awareness is a super definition including brand acquaintance, potential of being remembered, information and the ideas about the product (Bilgili\&Ozkul 2015).Ekhveh and Darvishi (2015) points out that brand awareness is associated with the information node in the memory; the ability of customers to recognize a brand under a variety of conditions reflects their awareness of the brand. Jamil \& Wong (2010) defines brand awareness as the brand recognition and brand recall of a brand. Brand awareness creates a great association in memory about a particular brand (Malik, Ghafoor, Hafiz, Riaz, Hassan, Mustafa\&Shahbaz 2013). Brand awareness is one of the main factors in creating brand added value and is also considered as one of the key factors affecting the knowledge level of consumers about the brand (Ekhveh\&Darvishi 2015).

\subsection{Brand association}

Jamil \& Wong (2010) are of the view that brand association is defined as the strength of benefits offered by the brand. Krishnan (1996) considered that "brand association" can be used as a general term to represent a link between two nodes, which suggest brand association in customers mind" (Chen, 2001). Brand association would help consumers search and deal with information (Boisvert, 2011). Moreover, brand association would provide consumers with a purchasing reason, because most brand associations are related to brand attributes, the target consumer market, and the benefits that consumers need, so that they form the foundation of brand loyalty and consumers' purchasing decisions (Len, Cind\& Lynn 2007).

\subsection{Product quality}

It is the totality of features and characteristics of a product or service that bears on its ability to satisfy given needs (Chavan, 2003). Jahanshahi, Gashti, Mirdamadi, Nawaser and Khaksar (2011) points out that if a product fulfils the customer's expectations, the customer will be pleased and consider that the product is of acceptable or even high quality. According to Akrani (2013) product quality means to incorporate features that have a capacity to meet consumer needs(wants) and gives customer satisfaction by improving products (goods) and making them free from any deficiencies or defects, it can also be those characteristics of a product that customer's wants and needs in exchange for monetary considerations. Therefore, from the authors' elucidations it can be noted that product quality refers to the ability of a product to consistently meet or exceed customers' requirements or expectations.

\subsection{Brand loyalty}

Brand loyalty is the attachment that a customer has to a brand (Kuscu\&Ozcam 2014). Said (2014) define brand loyalty as a positively biased emotive, evaluative and/or behavioural response tendency toward a branded, labeled or graded alternative or choice by an individual in his capacity as the user, the choice maker, and/or the purchasing agent. According to Jing, Pitsaphol\&Shabbir (2014) brand loyalty represents a commitment of the consumer to the brand which makes it as an intangible asset that reflects the company's price of the product or service. In addition, brand loyalty has been expressed as the consumer's positive feeling about the same brand, consumer purchasing the brand more frequent than the others as well as buying and using the same brand for a long time (Kocoglu, Tengilimoglu, Ekiyor\&Guzel 2015).

\subsection{Repurchase intention}

Repurchase intention refers to the probability or, chance of using the previous service provider again in the future (Upamannyu, Gulati, Chack\& Kaur 2015). Gounaris, Bimitraids and Stathakopoulos (2010) define repurchase intention as the customer's propensity to purchase products 
from the exact manufacturer over an extended duration of time. Repurchase intention, is the iterative process of purchasing goods and certain services from one particular store (Hellieret al., 2003) and the main reasons are the post-shopping experiences. Moreover, repurchase intention is a behavioral element, where there is an eagerness and ongoing interest in purchasing a product or a brand (Pather 2016). Therefore, drawing from the above elucidations it can be pointed out the repurchase intention is the likelihood the user will repurchase cosmetic brands in the future.

\section{Conceptual model and hypothesis development}

Based on a synthesis of the converging literature related to the research constructs, a conceptual model is proposed to guide the empirical study as shown in figure 1. The conceptual model suggest that brand awareness brand association product quality are the predictor variables while brand loyalty is the mediator variable and repurchase intention is the outcome variable. The hypothesized relationships between the research constructs will be discussed hereafter.

\section{Figure 1: Conceptual model}

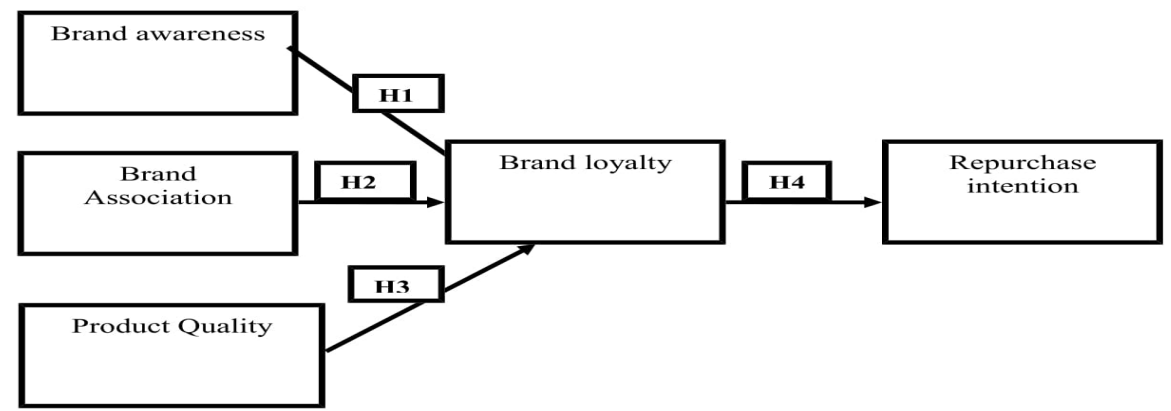

\subsection{Brand awareness and brand loyalty}

It is essential to note the important impact that brand awareness has on brand loyalty. Jing, Pitsaphol and Shabbir (2014) investigated the influence of brand awareness, brand image and perceived quality on brand loyalty. These authors found out that there is a significant statistically association between brand awareness and brand loyal Dhurup, Mafini and Dumasi (2014) investigated the impact of packaging, price and brand awareness on brand loyaly. The results of the multiple regression analysis showed that brand awareness contribute significantly to the prediction of brand loyalty. In addition, $\mathrm{Xu}, \mathrm{Li}$ and Zhou (2015) explored on the effect of brand awareness on brand loyalty and the results of their study showed that brand awareness has significant positive influence on brand loyalty. Yousaf, Zulfiqar, Altaf and Aslam (2012) conducted a study that focused on brand loyalty in the cosmetics industry and the results of their study indicated that there are the positive relationships between brand awareness and brand loyalty. Therefore, inferring from the literature and the empirical evidence above, it is hypothesized that:

H1: Brand awareness has a positive influence on brand loyalty

\subsection{Brand association and brand loyalty}

It is imperative to consider the association between brand association and brand loyalty. According to Atilgan, Aksoy and Akinci (2005) a strong brand association leads to higher brand loyalty. Azadi, Esfahani and Mohammadpoori (2015) conducted research which investigated the relationship between brand association and brand loyalty in the fans of private clubs in Iran. The findings of their research showed that there was significant relationship between brand association and brand loyalty in the fans of private club. Moreover, research done by Atilgan, Aksoy and Akinci (2005) revealed that if customers have more positive association toward a brand, they would be more loyalty toward a brand and the other way round. Thus, drawing from the above mentioned discussion, it is therefore hypothesized that:

\section{H2: Brand association has a positive influence on brand loyalty}




\subsection{Product quality and brand loyalty}

Product quality is also considered to be one of the contributing factors of brand loyalty. Khan, Zain-ul-Aabdean, Nadeem and Rizwan (2016) investigated the impact of product on brand Loyalty and the correlation analysis results showed that product quality is highly correlated with brand loyalty and have a positive and highly significant relationship. This means that an increase or decrease in product quality will cause increase or decrease in brand loyalty (Khan, Zain-ul-Aabdean, Nadeem \& Rizwan 2016).Reich, McCleary, Tepanon, \& Weaver, (2006) investigated the impact of product and service quality on brand loyalty. Their results showed that quick-service restaurants need to be more concerned with product quality especially in taste, freshness, and temperature, and focus on their overall service quality to build brand loyalty. Moreover, Ndukwe (2011) investigated the effect of product quality on brand loyalty and found out that product quality was more likely to lead to brand loyalty when customers judged the product as having very or high quality in the Nigerian telecommunications environment. Based on the above positions on the relationship between green promotion and competitive advantage, the following hypothesis is posited:

\section{H3: Product quality has a positive influence on brand loyalty}

\subsection{Brand loyalty and repurchase intention}

It is of significance to assess the relationship that exists between brand loyalties and repurchase intention. Lanza (2008) studied the relationship between brand loyalties and repurchase intention and found that there is a significant positive correlation between brand loyalty and repurchase intention. Said (2014) conducted a study which focused on mobile phone brand loyalty and repurchase intention. The results from Said's study established a positive significance correlation between brand loyalty and repurchase intention. Accordingly, it could be expected that brand loyalty will have a positive influence on repurchase intention. Mehdi, Mojganc and Masoud (2013) investigated the effective factors on brand loyalty and repurchase intention. They found out that brand loyalty is positively correlated to repurchase intention. Therefore, it can be hypothesized that:

\section{H4: Brand loyalty has a positive influence on repurchase intention}

\section{Research Methodology}

The researchers opted for a quantitative research design using a structured questionnaire, because it enhances the accuracy of results through statistical analysis (Berndt \&Petzer 2011) and as the elements of subjectivity associated with the qualitative approach (Du Plessis \&Rosseau 2007). In addition, the design was suitable to solicit the required information relating to brand awareness, brand association, product quality, brand loyalty and repurchase intention. Moreover, the approach enables to examine the causal relationships with the constructs utilised in the study.

\subsection{Sample frame and procedure}

The sample of the study comprised consumers with the Gauteng province of South Africa. This research employed a systematic random probability sample approach as it allowed an equal opportunity of being selected from the population, where the first sample was a simple random probability sample and thereafter a method of $n+3$ was adopted. Lazerwitz (1968) indicates that random sampling provides an appropriate appraisal of the populace, predominantly limiting sample prejudice and thereby making it additionally more representative than non-probability sampling techniques.

\subsection{Target population and data collection}

The population targeted for this study is all South African males, who potentially use male branded cosmetic products, between ages of 18 and 65, within the Gauteng region. The sampling unit was the individual consumer. For business related research, it is not viable to gather data from an entire population group; therefore the researchers adopted a random sampling method. This 
study incorporates collecting data from a practical cohort that would be sufficient to make accurate business decisions.

\subsection{Questionnaire design}

A structured self-administered questionnaire was adopted for this research and the questionnaire for this study comprised five sections; Section A, B, C, D, E \& F Section A required the respondents to fill in their background information. Sections B, C, D, E\& F measured brand awareness, brand association, product quality, brand loyalty and repurchase intention respectively. The research constructs were operationalized in accordance with previous works. Proper modifications were made to fit the current research context and purpose (Fagarasanu \& Kumar, 2002). There are a number of methods that assist researchers in gathering data of which one would involve the use of a scale. According to Vogt (1999), the Likert scale is commonly used which measures attitudes, knowledge, perceptions, values and behavioral changes. This study utilized a five-point Likert scale ranging from $1=$ strongly disagree to $5=$ strongly agree, to measure the data.

\subsection{Descriptive Results}

The structured, self-administered questionnaire was both hand delivered and electronically distributed. For both media of distribution there was distinctive guidance provided as to how to how to comprehensively complete the questionnaire. A covering letter accompanied the questionnaire stipulating the purpose of the study. In addition, the covering letter ensured respondents anonymity and confidentiality. 200 questionnaires were distributed with 150 being successfully completed. Therefore, the response rate for this study was 75 percent.

\subsection{Respondent Profile}

Table 1 presents the description of the participants. The respondents were asked to report their demographic information, including race, age, and male cosmetic brands frequently purchased.

Table 1: Respondents' profile

\begin{tabular}{|c|c|c|}
\hline Gender & Frequency & Percentase \\
\hline African & 34 & $22.7 \%$ \\
\hline White & 41 & $27.3 \%$ \\
\hline Asian & 63 & $42.0 \%$ \\
\hline Coloured & 12 & $8 \%$ \\
\hline Total & 151 & $100 \%$ \\
\hline Age & Frequency & Percentage \\
\hline $18-24$ & 8 & $5.3 \%$ \\
\hline $25-34$ & 61 & $40.7 \%$ \\
\hline $35-39$ & 48 & $32.0 \%$ \\
\hline $40-44$ & 12 & $8.0 \%$ \\
\hline $45-49$ & 12 & $8.0 \%$ \\
\hline Above 49 & 9 & $6 \%$ \\
\hline Total & 151 & $100 \%$ \\
\hline $\begin{array}{l}\text { Male cosmantic } \\
\text { bramds frequemtin } \\
\text { purchased }\end{array}$ & Frequency & Percentage \\
\hline Nivea for Men & 64 & $42.7 \%$ \\
\hline Vaseline for Men & 42 & $28.0 \%$ \\
\hline Dove for Men & 8 & $5.3 \%$ \\
\hline Gillette & 23 & $15.3 \%$ \\
\hline Clarins & 6 & $4.0 \%$ \\
\hline Kheils & 2 & $1.3 \%$ \\
\hline L'Oreal Men & 5 & $3.3 \%$ \\
\hline Total & 151 & $100 \%$ \\
\hline
\end{tabular}

As indicated in Table 1 below, this study shows that the majority respondents being of Asian at $(42 \%)$, following with White respondents at $(27.3 \%)$ and $(22.7 \%)$ and $(8 \%)$ for African and Colored respondents respectively. The most active age group in terms of purchasing cosmetic brands is that 25 - 34 years of age which constitute $40.7 \%$ of the total population, followed by those between $35-35$ years of age (32\%). Those in the age group of 40-44 as well as $45-49$ years of age constituted $(8 \%)$ of the total population. In addition, those in the age category of 18 - 24 years of age constituted $5.3 \%$ of the total population and lastly those above 49 years, constituting $6 \%$ only. Respondents indicated the male cosmetic brands they frequently purchased. Nivea for Men was the most frequently purchased brand representing $(42.7 \%)$ of the total population, this followed the Vaseline for Men brand which represented $(28.0 \%)$ of the total population, then followed by Gillette which 
represented $(15.3 \%)$ of the total population, in addition, Dove for Men represented $(5.3 \%)$ of the total population, and Clarins representing (4\%). Moreover, the last two brands frequently purchase, L'Oréal Men and Kheils representing (3.3\%) and (1.3\%) respectively.

6. Data analysis and results

A Microsoft Excel spread sheet was used to enter all the data and to make inferences of the data obtained, the Statistical Packages for Social Sciences (SPSS) and the Smart PLS software for Structural Equation Modeling (SEM) technique was used to code data and to run the statistical analysis. Smart PLS has emerged as a powerful approach to study casual models involving multiple constructs with multiple indicators (Chinomona \& Dubihlela 2014). In addition, Smart PLS supports both exploratory and confirmatory research, is robust to deviations for multivariate normal distributions, and is good for small sample size (Hair, Ringle \& Sarstedt 2013). Since the current study sample size is relatively small (150) Smart PLS was found more appropriate and befitting the purpose of the current study.

\subsection{Accuracy Assessment}

The same results of the path coefficients are tabulated in Table 2 depicting the Item to Total correlations, Average variance extracted (AVE), Shared Variance (SV), Composite Reliability (CR) and Factor Loadings.

Table 2: Measurement Accuracy Assessment and Descriptive Statistics

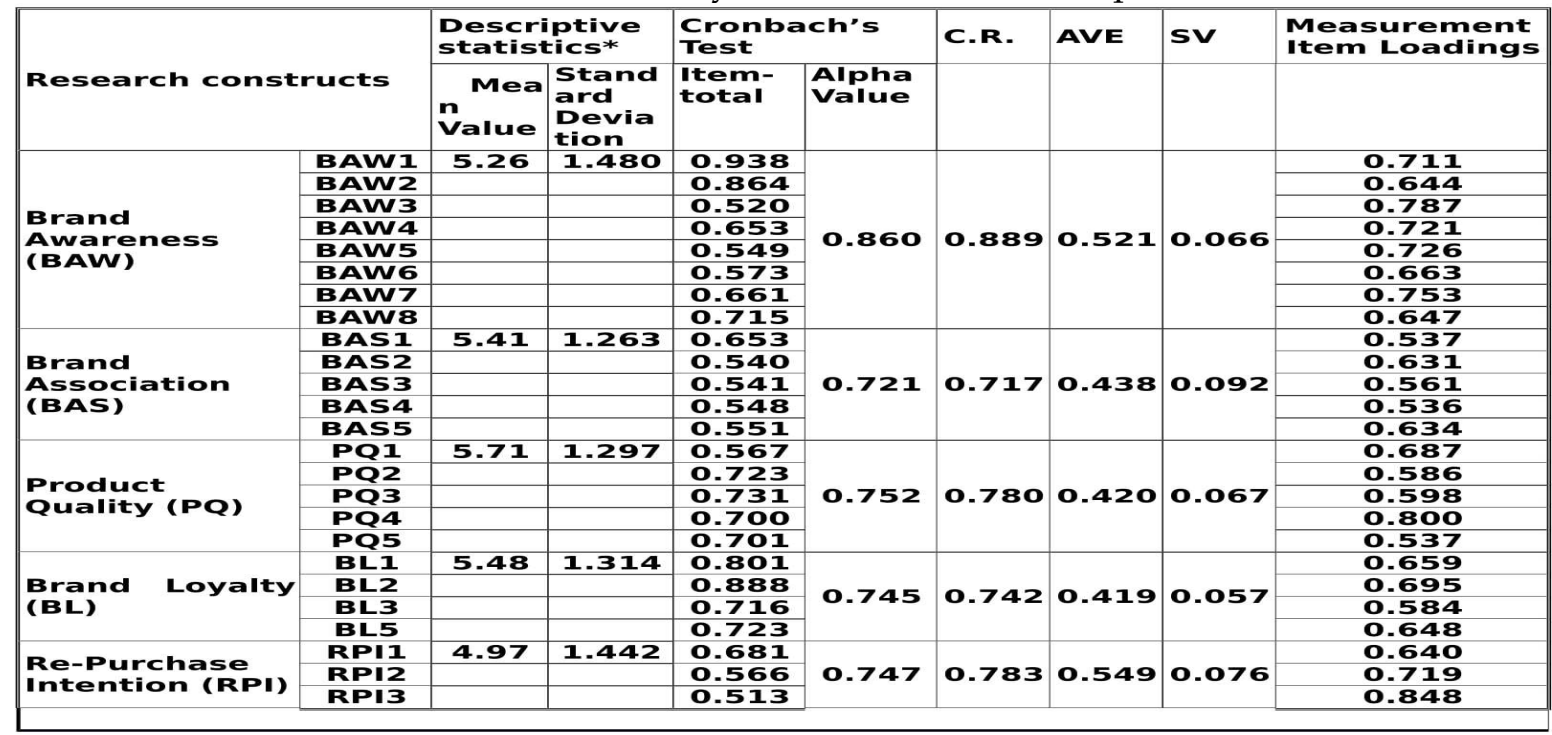

Brand Awareness = $($ BAW $)$; Brand Association = $($ BAS $)$; Product Quality = $(\mathrm{PQ})$; Brand Loyalty = $(\mathrm{BL})$; RePurchase Intention $=$ RPI

\subsection{Scale accuracy analysis}

BL4, and RPI 5 were deleted due to the fact that the factor loadings were below 0.5 which is the recommended threshold according to Anderson and Gerbin (1988). Table 2, above present the research constructs, Cronbach alpha test, Composite reliability (CR), Average variance extracted (AVE), shared variance (SV) and item loadings. The lowest item to total loading is RPI with 0.513 and the highest is BW1 with 0.938. On Factor loadings the lowest is BAS4 with 0.536 and the highest is 0.848 which is RPI3. This shows that the measurement instruments are valid. The lowest Cronbach alpha is 0.721 and the highest is 0.860 which shows that the constructs are very reliable and are explaining more that $50 \%$ of the variance.

\subsection{Inter-Construct Correlation Matrix}

To assess discriminant validity the AVE values were assessed. Malhotra defines AVE as the variance in the indicators or observed variables that are explained by the latent construct. A value of 0.40 or higher indicates a satisfactory measure (Anderson \& Gerbing 1988). AVE values of the 
construct should be greater than the shared variance between the construct and the other model constructs (Chin, 1998). Table 2 shows that all the AVE values are above the SV values respectively for all the research constructs, thereby confirming the existence of discriminant validity. Table 3 lists the correlation matrix with correlation among constructs. Nunnally and Bernstein, (1994) proves that one of the methods used to check on the discriminant validity of the research constructs was the evaluation of whether the correlations among latent constructs were less than 0.60. According to Nunnally and Bernstein (1994:38) "a correlation value of less than 0.60 is recommended in the empirical literature to confirm the existence of discriminant validity". As can be seen all the correlations are below the standard level of 0.60 which indicate the existence of discriminant validity. The diagonal values in bold stands for the Shared Variances (SV) for the respective research constructs. The Shared Variance is expected to be greater than the correlation coefficients of the corresponding research constructs. Table 3 above shows that the results further validate the existence of discriminant validity.

Table 3: Inter-Construct Correlation Matrix

\begin{tabular}{|c|c|c|c|c|c|}
\hline Variables & BAM & BAS & $\mathbf{P Q}$ & BL & RPI \\
\hline BAM & 1.000 & & & & \\
\hline BAS & 0.508 & 1.000 & & & \\
\hline $\mathbf{P Q}$ & 0.597 & 0.551 & 1.000 & & \\
\hline B L & 0.564 & 0.435 & 0.566 & 1.000 & \\
\hline RPI & 0.226 & 0.008 & 0.143 & 0.120 & 1.000 \\
\hline
\end{tabular}

Brand Awareness = $($ BAW $)$; Brand Association = $(B A S) ;$ Product Quality $=(P Q) ;$ Brand Loyalty $=(B L) ;$ Re-

\subsection{Path Model Results and Factor Loadings}

Purchase Intention $=$ RPI

Below is Figure 2, showing the path modelling results and as well as the item loadings for the research constructs. In the path model, brand awareness, brand association and product quality are the predictor variables. Brand loyalty is the moderator variable and re-purchase intention is the sole outcome/dependent variable.

Figure 2: Measurement and Structural Model Results

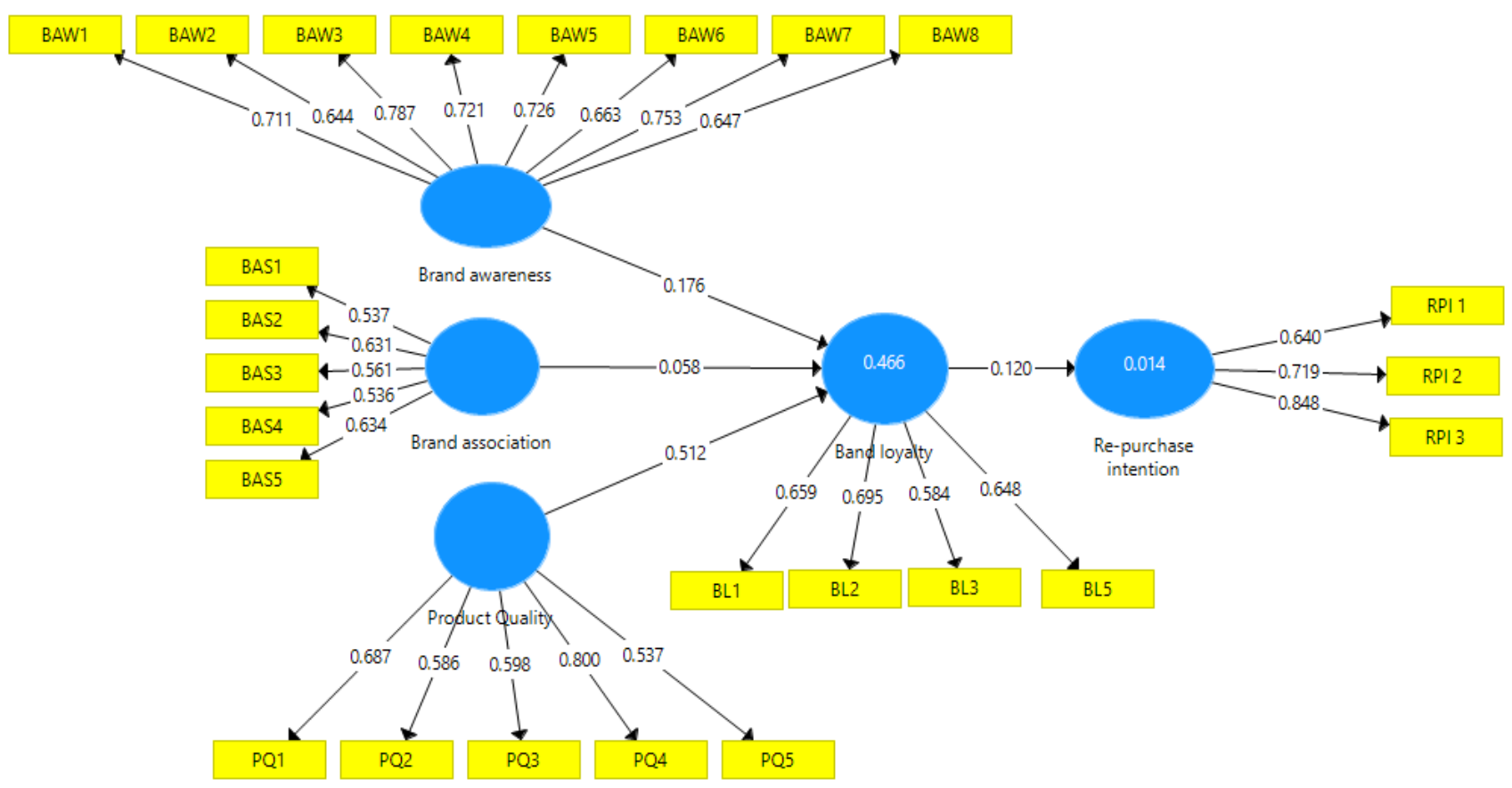


Table 4: Results of structural equation model analysis

\begin{tabular}{|c|c|c|c|c|}
\hline Path & $\begin{array}{l}\text { Hypothes } \\
\text { is }\end{array}$ & $\begin{array}{l}\text { Path } \\
\text { coefficients } \\
\text { ( } \beta)\end{array}$ & $\begin{array}{l}\text { T- } \\
\text { Statistic } \\
\text { S }\end{array}$ & $\begin{array}{l}\text { Decision } \\
\text { on } \\
\text { Hypothese } \\
\text { s }\end{array}$ \\
\hline $\begin{array}{l}\text { Brand Awareness (BAW) } \\
\text { Brand Loyalty (BL) } \\
\text { Brand Association (BAS) } \\
\text { Brand Loyalty (BL) }\end{array}$ & $\begin{array}{l}\text { H1 } \\
\text { H2 }\end{array}$ & $\begin{array}{l}0.176^{a} \\
0.058^{a}\end{array}$ & $\begin{array}{l}1.981 \\
0.447\end{array}$ & $\begin{array}{l}\text { Accept/ } \\
\text { Significant } \\
\text { Accept/in- } \\
\text { significant }\end{array}$ \\
\hline $\begin{array}{l}\text { Product Quality (PQ) } \\
\text { Brand Loyalty (BL) } \\
\text { Brand Loyalty (BL) }{ }^{\prime} \text { Re- } \\
\text { purchase intention (RPI) }\end{array}$ & $\begin{array}{l}\text { H3 } \\
\text { H4 }\end{array}$ & $\begin{array}{l}0.512^{\mathrm{a}} \\
0.120^{\mathrm{a}}\end{array}$ & $\begin{array}{l}4.283 \\
1.974\end{array}$ & $\begin{array}{l}\text { Accept/ } \\
\text { Significant } \\
\text { Accept/ } \\
\text { Significant }\end{array}$ \\
\hline
\end{tabular}

aSignificance Level $\mathrm{p}<.10$; bSignificance Level $\mathrm{p}<.05$; cSignificance Level $\mathrm{p}<.01$.

Table 4, above present the four hypothesized relationships, path coefficients, the $t$-statistics and the decision criteria. The value of the t-statistic will indicate whether the relationship is significant or not. T-statistics which is above 2 is accepted and shows a significant relationship. Drawing from the results provided in Table 4, four of the hypothesized relationships $(\mathrm{H} 1, \mathrm{H} 2, \mathrm{H} 3$ \& H4) are supported.

\section{Research Findings and Discussions}

7.1 Hypothesis One (H1): Brand Awareness (BAW) $\rightarrow$ Brand Loyalty (BA)

It can be observed in Figure 1 and Table 4 that H1, Brand Awareness (BAW) $\rightarrow$ Brand Loyalty (BL) is supported by the hypothesis result (0.176) and is significant at $t$-statistics 1.981 . The strength of the relationship is indicated by a path coefficient of 0.176 . This implies that brand awareness directly influences brand attachment in a positive significant way. High levels of brand awareness will lead to higher leads on brand loyalty.

\subsection{Hypothesis Two (H2): Brand Association (BAS) $\rightarrow$ Brand Loyalty (BL)}

Figure 1 and Table 4 above, indicate that H2, Brand Association (BAS) $\rightarrow$ Brand Loyalty (BL) emerged positively but has an insignificant influence as indicated by the path coefficient of (0.058) and the t-statistics (0.447). This implies that brand association (BAS) positively influences brand loyalty (BL) but has an insignificant impact on brand loyalty.

\subsection{Hypothesis Three (H3): Product Quality (PQ) $\rightarrow$ Brand Loyalty (BA)}

It is depicted in Figure 1 and Table 4 that H3, Product Quality (PQ) $\rightarrow$ Brand Loyalty (BA) is supported significantly. The t-statistics is 4.283 . The strength of the relationship is indicated by the path coefficient of 0.512 . This finding suggests that product quality has a direct strong positive effect on brand loyalty. So, the more a consumer fined a product is of good quality the more a consumer is loyal to the brand.

\subsection{Hypothesis four (H4): Brand Loyalty (BL) $\rightarrow$ Re-purchase intention}

It is depicted in Figure 1 and Table 4 that H3, Brand Loyalty (BL) $\rightarrow$ Re-purchase intention is supported significantly. The t-statistics is 1.974 . The strength of the relationship is indicated by the path coefficient of 0.120 . This finding suggests that brand loyalty has a direct strong positive effect on re-purchase intention. Thus, the more a consumer is loyal to a brand the more a consumer intents to repurchase the brand.

\section{Academic, practical and policy implications for the study}

The present study offers implications for academicians. An investigation of the research findings indicate that Product Quality (PQ) $\rightarrow$ Brand Loyalty (BA) has the strongest influence on each other as indicated by a path coefficient of $(0.512)$ when compared to other research constructs.Thus, for academicians in the field of brand management this finding enhances their understanding of the relationship between product quality and brand loyalty as this is a useful contribution to existing literature on these two variables. 
On the practitioners 'side, this study submits that marketers or brand managers of male cosmetic brands can benefit from the implications of these findings. For example, given the robust relationship between brand loyalty and repurchase intention (0.473), brand managers ought to pay attention on selling cosmetic products which are of high quality, enhancing brand awareness campaigns for cosmetic products as well as promotions for consumers to be associated with brands in order for consumers to be loyal and to repurchase cosmetic brands. The consumers can also spread through word of mouth to other male friends, brothers or fathers within their families thereby boosting their production and profits.

Moreover; the present study offers implications for policy makers (the government or retail associations) who have been developing brand strategies to improve the performance brands. Precisely; policies or strategies which exist in their respective departments or associations can be modified or created in order to make their consumers repurchase their brands. Thus, the results which have been obtained from this study may be used to generate new policies and revision of the existing policies.

\section{Limitations and Future Research Suggestions}

Limitations were observed during this research. First, the study was restricted to four factors only; namely brand awareness, brand association, product quality, brand loyalty and repurchase intention. Future research could also include factors that influence the repurchase intention of cosmetic male brands such as brand innovation and brand love. In addition, the results are based on a sample of 150 respondents which is not a bigger sample. This makes it difficult to generalize the results to other contexts in South Africa since South Africa has 9 provinces. Other researchers could make use of large sample sizes in order to get more representative views. This study focused on a purely quantitative research approach, other researchers could also try to use a mixed method approach or qualitative research so that in depth views of male consumers for cosmetic brands in South Africa.

\section{Conclusion}

The purpose of this study was to investigate the influence of brand awareness, brand association and product quality on brand loyalty and repurchase intention among male consumers of cosmetic brands in South Africa. In particular, four hypotheses were postulated. To test the proposed hypotheses, data were collected from Gauteng Province in South Africa. The empirical results supported all the posited research hypotheses in a significant way except $\mathrm{H} 2$. The study authenticates that factors such as brand awareness, brand association, and product quality are instrumental in stimulating brand loyalty as well as repurchase intention in South Africa.

11. References

Ajzen, I. 1985. From intentions to actions: A theory of planned behavior. In J. Kuhl \& J. Beckman (Eds.), Action-control: From cognition to behavior (pp. 11-39). Heidelberg, Germany: SpringerVerlag.

Anderson, E. W., Fornell, C., \& Lehmann, D. 1994. Customer Satisfaction, Market Share, and Profitability: Findings from Sweden. Journal of Marketing, 58(3), pp. 53-66.

Anderson, J.C \& Gerbing, D.W. 1988. Structural equation modeling in practice: a review and recommended two steps approach, Psychological Bulletin, 103(3), pp. 411-423.

Atilgan, E., Aksoy, S., \&Akinci, S. 2005. Determinants of the brand equity: A verification approach in the beverage industry in Turkey. Marketing Intelligence $\mathcal{E}$ Planning, 23(3), pp. 237-248.

Atilgan, E., Aksoy, S., \& Akinci, S. 200. Determinants of the brand equity: A verification approach in the beverage industry in Turkey. Marketing Intelligence \& Planning, 23(3), pp. 237-248.

Azadi, E.M 2015.Relationship between brand association and brand loyalty in the fans of private clubs in Iran. Biomed Pharmacol Journal, 8(2), pp. 1-8 
Bilgili, B., \&Ozkul, E. 2015. Brand Awareness, Brand Personality, Brand Loyalty and Consumer Satisfaction Relations in Brand Positioning Strategies (A Torku Brand Sample). Journal of Global Strategic Management, 9(2),pp. 89-106.

Boisvert, J., 2011. Conceptualization and modelling of the process behind brand association .transfer. International journal of Market Research, 53(4), 541-556

Chavan, R.B. 2003.Manual on quality Assurance for Khadi. Mahatma Gandhi Institute of Rural Industrialization a Collaborative Project of KVIC \& IITD

Chen, A.C.H 2001.Using free association to examine the relationship between the characteristic of brand association and brand equity.Journal of Product $\mathcal{E}$ Brand Management, Decision Processes, 50(2), 179-211.

Dhurup, M., Mafini, C., \&Dumasi, T. 2014. The impact of packaging, price and brand awareness on brand loyalty: evidence from the paint retailing industry: original research. Act a Commercii, 14(1), 1-9.

Ekhveh, A \& Darvishi, A.Z. 2015. The Impact of Brand Awareness on Re-purchase Intention of Customers With Trilogy of Emotions Approach (Case Study for Cell Phones). Applied mathematics in Engineering, Management and Technology, 3(4), 25-30.

Gounaris, S., Bimitraids, S., \& Stathakopoulos, V. 2010. An examination of the effects of service quality and satisfaction on customers behavioral intentions in e-shopping. Journal of services marketing, 24(2), pp. 142-156.

Hellier,P.H., Geursen, G.M., Carr, R.A \& Rickard, J.A 2003. "Customer repurchase intention: A general structural equation model", European Journal of Marketing, 37(11/12), pp. 1762 - 1800.

Hennig-Thurau, T. \& Klee, A. 1997. The Impact of Customer Satisfaction and Relationship Quality on Customer Retention: A Critical Reassessment and Model Development. Psychology $\mathcal{E}$ Marketing, 14(8), pp. 737-764.

Itsarintr, K. 2011. Factors Affecting Positive Word of Mouth and Repurchase Intention: A Case Study of Clothing Retailers in Bangkok. AU-GSB e-JOURNAL, 4(2),pp.92-99.

Jahanshahi, A.A., Gashti, M.A.H., Mirdamadi, S.A., Nawaser, K \&Khaksar S.M.S 2011. Study the Effects of Customer Service and Product quality on Customer Satisfaction and Loyalty. International journal of Humanities and Social Science, 7(1), pp. 253-259

Jamil, B., \& Wong, C. H. 2010. Factors influencing repurchase intention of smartphones. Journal of Marketing Research, 4(12),pp. 289-294.

Jing, Z., Pitsaphol, C., \&Shabbir, R. 2014. The Influence of Brand Awareness, Brand Image and Perceived Quality on Brand Loyalty: A Case Study of Oppo Brand In Thailand. Interdisciplinary Journal of Contemporary Research in Business, 5(12), pp. 10-21.

Khan, M. N., Zain-ul-Aabdean, M. S., Nadeem, B., \& Rizwan, M. 2016. The Impact of Product and Service Quality on Brand Loyalty: Evidence from Quick Service Restaurants. American Journal of Marketing Research, 2(3), pp. 84-94

Kocoglu, C., Tengilimoglu, D., Ekiyor, A \&Guzel, A. 2015. The Effects of Brand Loyalty on the Consumer Buying Behaviors: The Example of Perfume in the Province of Ankara. International Journal of Humanities and Management Sciences, 3(5), pp. 318-323.

Krishnan, H.S 1996. Characteristics of memory association: A customer- based brand equity perspective. International Journal of Research in Marketing, 13, pp. 389-405

Kuscu, A \& Ozcam 2014. Analyzing Factors Affecting Repurchase Intention During Gezi Park Brand Protests. European Journal of Business and Management, 6(38), pp. 177-188.

Lanza, K.M. 2008.The antecedents of Automotive Brand Loyalty and Repurchase Intentions, doctoral dissertation, University of Phoenix.

Len T.W, Cindy M, Lynn M.M 2007. Research issues in building brand equity and global brands in the PC market. Journal of Marketing Management, 3(1), pp. 137-155.

Lin, C.S \& Chen, C.F. 2010. Application of theory of planned behavior on the study of workplace Dishonesty, 2010 International Conference on Economics, Business and Management, 
Malik, M. E., Ghafoor, M. M., Hafiz, K. I., Riaz, U., Hassan, N. U., Mustafa, M., \&Shahbaz, S. 2013.Importance of brand awareness and brand loyalty in assessing purchase intentions of consumer. International Journal of Business and Social Science, 4(5), pp. 167-171.

Mehdi, J.S., Mojganc, K., \&Masoud, J. 2013. Investigation of the effective factors on brand loyalty and repurchase intention (Case study: Iranian Consumers). Research journal of recent sciences. 2(2), pp. 10-17.

Ndukwe, G.I. 2011. The Effect of Product Quality on Brand Loyalty. Study of MTN. https://www.academia.edu/1766154/The_Effect_of_Product_Quality_on_Brand_Loyalty._A Study_of_MTN. [Accessed on, 20, 03-14].

Nunnally, J.C \& Bernstein. 1994. Psychometric theory. New York: McGraw-Hill.

Pamacheche, R., Chinomona, R., \& Chuchu, T. (2016). Management's Commitment, Education and Ethics on Organisational Entrepreneurship: The Case of South African Non-Profit Organisations. Journal of Economics and Behavioral Studies, 8(4), 133-143.

Pather, P. 2016. Brand equity as a predictor of repurchases intention of male branded cosmetic products in South Africa. Business \& Social Science Journal, 1(3), pp. 193-247.

Reich, A. Z., McCleary, K. W., Tepanon, Y., \& Weaver, P. A. 2006. The impact of product and service quality on brand loyalty: An exploratory investigation of quick-service restaurants. Journal of Foodservice Business Research, 8(3), pp. 35-53.

Said, H. 2014. Mobile phone brand loyalty and repurchase intention. European Journal of Business and Management, 6(26), pp. 69-72.

Smith, J. R., Terry, D. J., Manstead, A. S., Louis, W. R., Kotterman, D., \& Wolfs, J. 2007. Interaction Effects in the Theory of Planned Behavior: The Interplay of Self Identity,and Past Behavior. Journal of Applied Social Psychology, 37(11), pp. 2726-2750.

Sun, H., Kim, S., \&Heo., E.J. (2016). What Attracts Chinese Customers to Repurchase Korean cosmetcis? Advanced Science and Technology Letters, 126 (Business2016), pp. 55-60.

Tsai, C.Y. 2010. Applying the theory of planned behavior to explore the independent travellers' behavior, African Journal of Business Management, 4(2), pp. 221-234.

Upamannyu, N. K., Gulati, C., Chack, A., \& Kaur, G. The effect of customer trust on customer loyalty and repurchase intention: the moderating influence of perceived csr. International Journal of Research in IT, Management and Engineering, 4(5), pp. 1-31.

Yousaf, U., Zulfiqar, R., Altaf, M., \& Aslam, M. 2012.Studying brand loyalty in the cosmetics industry. Log-Forum, 8(4), pp. 327-337.

Xu, F., Li, Y., \& Zhou, J. 2015. Brand Awareness for Entrepreneurial Hotel Chains: Perceived Quality and Brand Loyalty. Anthropologist, 19(3), pp. 763-771.

Zboja, J. J., \& Voorhees, C. M. 2006.The impact of brand trust and satisfaction on retailer repurchase intentions. Journal of Services Marketing, 20(6), pp. 381-390. 